ISSN [E]: 2477-0515 ISSN [P]: 2339-0794

DOI: $10.26858 /$ jnp.v9i1.20299

Online: https://ojs.unm.ac.id/nalar

\title{
PEMANFAATAN TEKNOLOGI DALAM PEMBELAJARAN DARING ERA COVID- 19 PADA PESERTA DIDIK KELAS V SEKOLAH DASAR
}

\author{
Maulidyanawati Aqmarina Ma'ruufah ${ }^{1}$, Rivan Gestiardi ${ }^{2}$, Chumdari ${ }^{3}$ \\ 1.2.3 Program Pascasarjana, Universitas Sebelas Maret, Surakarta, Indonesia \\ maulidyanawati_98@student.uns.ac.id
}

\begin{abstract}
Abstrak
Penelitian ini bertujuan untuk memaparkan pemanfaatan teknologi dalam era pandemi pada peserta didik kelas $\mathrm{V}$ di sekolah dasar. Penelitian ini menggunakan metode penelitian kualitatif deskriptif. Teknik mengumpulkan data menggunakan observasi serta wawancara di sekolah dasar. Subjek dalam penelitian ini sebanyak 20 siswa SDN Kembangbilo 1 Tuban kelas V. Teknik pengambilan subjek penelitian ini menggunakan kualitatif dengan random sampling. Hasil penelitian menemukan adanya beragam penggunaan aplikasi yaitu aplikasi WhatsApp Massenger, Zoom Cloud Meeting, Google Classroom, dan Google Form. Beberapa aplikasi tersebut dinilai menjadi alternatif terhadap pelaksanaan proses belajar daring di era COVID-19 yang didapatkan pada pembelajaran daring. Perlu diketahui terdapat kendala/hambatan dalam penerapan proses belajar daring, baik karena terkendala signal serta siswa yang tidak memiliki smartphone guna melaksanakan proses pembelajaran dari jarak jauh. Implikasi dari penelitian ini adalah perpaduan teknologi yang sudah cukup baik namun hal perlu dievaluasi lebih lanjut terutama terkait kendala yang dihadapi pada siswa sekolah dasar. Berdasarkan hal tersebut, dapat disimpulkan bahwa pemanfaatan teknologi yang diterapkan kepada peserta didik kelas V di Sekolah Dasar dapat menjadi solusi terhadap situasi pandemi saat ini melalui beragam aplikasi yang memiliki beragam fitur.
\end{abstract}

Kata kunci: COVID-19, online, sekolah dasar, teknologi.

\section{THE USE OF TECHNOLOGY IN ONLINE LEARNING IN THE COVID 19 ERA IN CLASS V ELEMENTARY SCHOOL STUDENTS}

\begin{abstract}
This study aims to explain the use of technology in the pandemic era to fifth grade students in elementary schools. This study uses descriptive qualitative research methods. The technique of collecting data is using observation and interviews in elementary schools. The subjects in this study were 20 students of SDN Kembangbilo 1 Tuban class $V$. The technique of taking the subject of this study used qualitative random sampling. The results of the study found that there were various uses of applications, namely the WhatsApp Messenger application, Zoom Cloud Meeting, Google Classroom, and Google Form. Some of these applications are considered an alternative to the implementation of the online learning process in the COVID-19 era that is obtained in online learning. It should be noted that there are obstacles in the application of the online learning process, both because of signal constraints and students who do not have smartphones to carry out the learning process remotely. The implication of this research is that the combination of technology is quite good, but things need to be evaluated further, especially regarding the obstacles faced by elementary school students. Based on this, it can be concluded that the use of technology applied to fifth grade students in elementary schools can be a solution to the current pandemic situation through various applications that have various features.
\end{abstract}

Keyword: COVID-19, online, elementary education, technology.

\section{PENDAHULUAN}

Pandemi COVID-19 terjadi pada tahun 2019 hingga berakhirnya tahun 2020, virus ini terinfeksi sebanyak lebih 200 negara di seluruh dunia. Indonesia merupakan negara yang terinfeksi oleh virus tersebut. Organisasi dunia World Health 
Organization (WHO) menuturkan COVID-19 adalah pandemi yang melanda secara garis besar negara di dunia COVID-19 dan bencana nasional non-alam oleh pemerintah Indonesia. Middle East Respiratory (MERS) terhadap Corona virus merupakan salah satu virus yang memberikan gejala persis. ialah Corona virus Disease 2019 (COVID19) dianggap penyakit baru yang belum pernah ditemukan manusia dahulu yang ditandai demam, batuk, hingga sesak napas yang merupakan tandatanda terinfeksi COVID-19. dengan rata-rata masa inkubasi mencapai 6 hari - 14 hari [1]. Pemerintah langsung mengambil kebijakan untuk mencegah penularan rantai virus COVID-19. Berbagai kebijakan yang dipilih yaitu dengan menganjurkan masyarakat wajib memakai masker, cuci tangan dengan sabun, jaga jarak maupun menjauhi keramaian. Pada bidang pendidikan, himbauan terkait kebijakan tentang pembatasan sosial diterapkan dengan pembelajaran dalam jaringan (daring), bekerja dari rumah (WFH) serta beribadah di rumah. Dimulai pada tanggal 16 Maret 2020, pemerintah memutuskan untuk semua kegiatan belajar-mengajar dilaksanakan melalui pembelajaran daring. Hal ini dilakukan oleh pemerintah sebagai upaya pemutusan rantai virus corona atau akrab disebut COVID-19.

Dunia teknologi dimulai sejak abad 21 atau dikenal dengan sebutan era digital, dimana hal ini mampu mempengaruhi sistem pendidikan salah satunya ialah proses pembelajaran didalam dunia pendidikan. Dampak dari kemajuan dunia pendidikan yakni teknologi informasi dan komunikasi [2]. Foster \& Rosenberg pada Ref. [3] menyatakan perkembangan TIK terhadap pembelajaran sudah mengalami lima transformasi, yaitu satu transformasi dari pelatihan menjadi keterampilan, dan satu transformasi dari ruang belajar menjadi fleksibel. Ada 2 jenis, 3 jenis transisi dari ruang kelas ke daring, internet menggeser 4 fasilitas fisik, dan waktu siklus terganti oleh waktu nyata. Seiring dengan perubahan kebiasaan, demikian pula mata pelajaran yang harus diterapkan, dan tentunya harus dilanjutkan, agar siswa SD dapat terus belajar dan meningkatkan kemampuan belajarnya.

Revolusi dapat merubah segala kondisi seperti pendidikan yang mana diawali dari pertemuan langsung dan guru hanya menerangkan pelajaran dalam kelas melalui berbagai persiapan mengajar yang telah dipersiapkan sebelumnya. Namun hal ini menjadi berbalik karena guru memberikan pembelajaran melalui jarak jauh contohnya dapat memberikan materi melalui video kreatif yang dibuat oleh guru atau melalui aplikasi smartphone guna memudahkan peserta didik untuk memahami materi. Penilaian juga yang diawali menggunakan kertas berubah menjadi digital, guru bisa menilai peserta didik lebih variatif dan efisien karena guru mampu melihat seperti pemberian kuis online, permainan online, forum online dengan melihat peserta didik yang mana saja terlibat aktif pada pembelajaran. Penilaian dalam sistem digital memudahkan guru untuk menilai secara efisien, terjangkau dan simpel.

Pendidikan online ialah salah satu wujud pendidikan yang memanfaatkan jaringan internet yang mempunyai aksesibilitas, konektivitas, fleksibilitas serta keahlian untuk menciptakan bermacam tipe interaksi pendidikan [4]. Pendidikan online ataupun pembelajaran secara daring dapat difungsikan dengan teknologi semacam virtual class, online teks, video, animated, voice note, email, telepon, conference, serta video streaming secara online, bisa berinteraksi dengan sekelompok orang yang tidak terbatas jumlahnya, serta free ataupun berbayar [5]. Bilfaqih dan Qomarudin dalam Ref. [6] Oleh sebab itu, pendidikan online bisa dimaksud selaku pendidikan dengan memanfaatkan internet, jaringan eksternal, ataupun PC global serta tersambung secara langsung (online).

Model pembelajaran daring menjadi suatu pilihan yang tepat bagi guru dalam merancang pembelajaran menjadi efektif serta efisien dalam rangka pencapaian tujuan pembelajaran yang diinginkan. Model ini dirancang guna siswa memperoleh pengalaman berkesan dalam setiap pembelajaran serta guru dapat menjadikan pedoman terhadap pelaksanaan kegiatan dalam mengajar [7].

Pada dasarnya pembelajaran daring mengacu pada konsep E-learning yang mengarah pada pemanfaatan TIK untuk mendukung proses belajar daring diantaranya melalui penggunaan media komunikasi seperti WhatsApp serta memanfaatkan berbagai aplikasi Google Classroom, YouTube, maupun aplikasi Zoom yang bisa membantu tersampaikannya tujuan pembelajaran serta dapat mempertemukan guru dan peserta didik dengan 
dibantu pengawasan orangtua sehingga diharapkan proses belajar mengajar tersampaikan dengan baik.

Untuk mengetahui pemanfaatan teknologi terhadap school from home di masa pandemi COVID-19 maka diperlukan sudut pandang secara langsung dari pelaku pembelajaran daring. Hal tersebut memiliki tujuan sebagai pengetahuan berbagai macam pemanfaatan teknologi yang digunakan terhadap proses belajar daring beserta kendala yang ditemukan. Objek penelitian yang diambil yaitu pendidik serta peserta didik SDN Kembangbilo 1 Tuban kelas V. SDN Kembangbilo 1 Tuban berada tidak jauh dari pusat kota Tuban, harapannya dengan keberadaan SD tersebut dapat menemukan berbagai informasi yang dibutuhkan. Peserta didik Kelas V merupakan peserta didik kelas tinggi yang terletak pada tahap pengoperasian konkret dibuktikan oleh peserta didik yang dapat menganalisis, mencoba, dan melakukan eksperimen. Peserta didik saat masanya telah memahami teknologi, sehingga dianggap bisa menerima teknologi dalam perkembangan zaman. Di sisi lain, melalui pembelajaran online menurut Nakayama, Yamamoto, Santiago, dan Bernardino dalam Ref. [8] menjelaskan semua literatur tentang E-learning menunjukkan bahwa tidak semua siswa berhasil belajar secara online. Hal ini disebabkan oleh karakteristik lingkungan belajar dan siswa itu sendiri. Parker \& Amanda dalam Ref. [9] menyatakan hasil survei menemukan pembelajaran daring dapat meningkatkan potensi menyontek lebih besar [10]. Unger dan Meiran dalam Ref. [11] menjelaskan pembelajaran daring mengarah pada hasil akademis yang lebih rendah dibanding pengajaran secara tatap muka. McKenna, Finamore, Valerie Hewitt, Watson, Millam, dan Reinhardt Ref. dalam [12] berpendapat bahwa pembelajaran daring mengurangi sosialisasi dan komunikasi antar peserta didik.

Berdasarkan kajian tersebut peneliti tertarik untuk meneliti tentang pemanfaatan teknologi dalam pembelajaran daring era COVID-19 kelas V SDN Kembangbilo 1 Tuban. Penelitian ini bertujuan untuk memaparkan pemanfaatan teknologi dalam era pandemi. Penelitian yang serupa dengan penelitian ini sudah dilakukan oleh Astini pada Ref. [13] mengemukakan pemanfaatan teknologi yang digunakan yaitu grup WhatsApp, Google Classroom, Google Docs atau Google Form, maupun Zoom meeting. Selain itu Wilson dan Narayan pada Ref.
[14] menjelaskan aplikasi yang digunakan dalam proses belajar daring yaitu: WhatsApp, Google Classroom, Edmodo, Zoom, Google Meet, Webex, Loom, Quizizz, dan Duolingo. Pada penelitian Pakpahan dan Ref. [15] menerangkan teknologi dan informasi yang digunakan terhadap proses belajar daring di masa pandemi COVID-19 yaitu: WhatsApp, Google Classroom, Zoom, dan YouTube.

\section{METODE PENELITIAN}

Metode penelitian ini menggunakan pendekatan kualitatif dimana terdapat pendeskripsian makna, proses dan menghasilkan pemahaman secara optimal tentang berbagai situasi [16]. Selain itu, metode penelitian deskriptif kualitatif yakni prosedur penelitian yang menghasilkan data deskriptif berupa kata-kata, perkataan dan perilaku yang dapat diamati dari subjek [17]. Suatu metode pengecekan status manusia, objek, kondisi, sistem pemikiran atau kejadian terkini [18].

Data penelitian kualitatif ini berupa data baik berupa kalimat ataupun narasi. Data kualitatif yang diperoleh dari sumber data berupa deskripsi berkaitan dengan pemanfaatan teknologi dalam pembelajaran daring era COVID-19 kelas V SDN Kembangbilo 1 Tuban. Sumber data yang diperoleh pada penelitian ini yakni guru dan 20 siswa SD Negeri Kembangbilo 1 Tuban Kelas V. Teknik pengambilan subjek penelitian ini menggunakan kualitatif dengan random sampling. Teknik pengumpulan data berupa pelaksanaan observasi pembelajaran serta wawancara yang yang dilakukan kepada guru serta peserta didik SD Negeri Kembangbilo 1 Tuban kelas V.

Keabsahan data dilakukan melalui triangulasi teknik serta triangulasi sumber. Triangulasi pada teknik pengumpulan melalui cara dengan membandingkan teknik wawancara dan observasi. Sedangkan triangulasi sumber didapatkan dari sumber data yang diperoleh dari informan berasal dari guru serta peserta didik SD Negeri Kembangbilo 1 Tuban kelas V. Reduksi data, penyajian data, dan verifikasi atau kesimpulan merupakan tahapan analisis data dari penelitian ini.

\section{HASIL DAN PEMBAHASAN}

Hasil observasi dan wawancara menyatakan bahwa guru serta peserta didik di SDN Kembangbilo 1 Tuban pada tanggal 9 November, 2019 didapatkan hasil dari pemanfaatan teknologi terhadap proses belajar pada masa pandemi COVID-19 
dilaksanakan dengan memanfaatkan beberapa aplikasi. Semua aplikasi yang digunakan dapat diunduh pada smartphone.

Aplikasi yang pertama yaitu aplikasi WhatsApp messenger. Aplikasi WhatsApp ialah aplikasi yang dapat mengirimkan teks, suara, maupun video. Terdapatnya fitur grup di Whatsapp sehingga setiap peserta didik bisa mengirim pesan secara mudah dan langsung pada peserta didik lainnya [19]. WhatsApp dimanfaatkan dari guru dan peserta didik agar dapat mengkoordinasi pembelajaran serta memberikan berbagai informasi mengenai pembelajaran. pelaksanaan pembelajaran dengan menggunakan aplikasi WhatsApp sama seperti saat di kelas, melalui hasil proses observasi dan wawancara guru maupun peserta didik, aplikasi WhatsApp dimanfaatkan dengan langkah sebagai berikut: (1) Sebelum memulai pembelajaran dimulai dengan membaca do'a dan presensi terlebih dahulu, (2) Guru mengirimkan link materi pembelajaran atau foto yang berisikan materi, petunjuk pengerjaan soal dan soal evaluasi, kemudian dikirimkan di grup WhatsApp. (3) Peserta didik mengerjakan instruksi dari guru menurut arahan dari grup WhatsApp, dalam pengerjaannya dikerjakan sendiri, dibantu orang tua, saudara ataupun orang terdekat lainnya, (4) Peserta didik mengumpulkan tugas dengan cara memfotokan hasil pekerjaannya yang kemudian dikirimkan pada guru atau Google Classroom. Guru menilai aplikasi ini dianggap efektif terhadap pelaksanaan proses belajar daring di era COVID-19. Astini dalam Ref. [13] menyatakan pembelajaran daring dengan memberikan tugas dengan WhatsApp Group dianggap tepat terhadap situasi mendesak disebabkan oleh wabah COVID-19 ini. Hal tersebut menunjukan bahwa pemanfaatan teknologi ini cukup membantu meskipun pada dasarnya tidak dapat mengcover pembelajaran seperti pada pembelajaran tatap muka.

Aplikasi yang kedua yaitu aplikasi Zoom Cloud Meeting. Melalui aplikasi Zoom sebagai media pembelajaran menawarkan fitur video. Aplikasi Zoom Cloud Meeting menyediakan fitur berkomunikasi secara langsung bersama siapapun melalui video. Melalui hasil observasi dan wawancara yang telah terlaksana bersama guru serta siswa, langkah awal yang dilakukan oleh guru yaitu dengan menyiapkan link dan membagikan link tersebut pada grup WhatsApp yang didapatkan dari aplikasi Zoom. Peserta didik diminta mengunduh zoom cloud meeting di smartphone nya oleh guru. Setelah itu guru memastikan bahwa peserta didik sudah memahami cara melakukan pembelajaran dapat berjalan dengan baik. Aplikasi Zoom memang cocok digunakan sebagai media pembelajaran [20]. Zoom ialah sebuah aplikasi yang berfungsi menjadi media komunikasi jarak jauh baik dalam bentuk video conference, chat serta dapat merancang pembelajaran online. Aplikasi dapat menampung satu pertemuan virtual sebanyak lebih dari 1000 peserta, fitur tersebut antara lain Ismawati dan Prasetyo dalam Ref. [21] menyatakan aplikasi ini digunakan untuk melaksanakan pertemuan tatap muka. Penggunaan aplikasi Zoom dalam pembelajaran tidak dilaksanakan setiap hari, namun hanya beberapa kali dalam satu minggu. Melalui penggunaan aplikasi Zoom Cloud Meeting, guru bersama siswa bisa berinteraksi secara virtual dalam pembelajaran daring. Berdasarkan penelitian Snelson, Rice, dan Wyzard pada Ref. [21] menyimpulkan bahwa video conference (Zoom Meeting) mampu menjadi solusi pembelajaran daring, membuat peserta didik mudah dalam memahami penyampaian materi dari guru dikarenakan berlangsung secara langsung aninteraktif dalam bentuk media pembelajaran.

Kendala yang ditemukan dalam penggunaan aplikasi Zoom Cloud Meeting dalam pembelajaran ini peserta didik kurang antusias dalam mengikuti pertemuan yang sudah dijadwalkan oleh guru. Hal ini dikarenakan peserta didik tidak memiliki aplikasi tersebut pada android yang dimilikinya yang disebabkan oleh kurangnya kapasitas memori yang ada pada android.

Aplikasi yang ketiga adalah YouTube. YouTube yang saat ini menjadi trend di masyarakat dapat dimanfaatkan dalam berbagai proses pembelajaran yang menarik dan tidak monoton, dengan adanya akses yang mudah dan tidak dibatasi oleh waktu dan ruang, hal ini memudahkan peserta didik memperoleh bahan belajar serta bentuk penampilan terlihat nyata dan menarik. Menurut Ref. [22] YouTube merupakan sebuah sarana dalam membagikan video yang saat populer saat ini. YouTube menjadi sebuah layanan web video sharing terhadap para pengguna dalam mengunggah, mengunduh, searching video, menyaksikan, berdiskusi atau tanya jawab secara gratis. Adapun video musik, film, bahkan TV, dan juga hasil video dari para pengguna YouTube 
sendiri. YouTube menjadi layanan online video provider yang sangat fenomenal di dunia hingga tidak terdapat batas durasi dalam mengunggah video. Melalui hasil observasi dan wawancara terhadap guru bersama siswa tentang penggunaan aplikasi YouTube, guru membagikan link video pembelajaran atau materi baik yang dibuat sendiri oleh guru maupun materi yang bisa ditelusuri langsung dari laman YouTube, dengan melakukan hal tersebut peserta didik dapat mudah memahami materi serta dapat menonton secara berulang kali materi yang ada hingga peserta didik memahami betul materi tersebut. Kelebihan YouTube dalam media belajar daring yaitu: 1) Informatif, maksudnya adalah adanya informasi yang sangat luas dari berbagai perkembangan ilmu pengetahuan yang saat ini terjadi. 2) Cost effective dengan cara gratis dengan hanya melalui jaringan internet 3 ) Potensial, artinya memberikan pengaruh terhadap pendidikan karena terdapatnya berbagai video. 4) Praktis dan lengkap, maksudnya adalah pengguna bisa mengakses dengan mudah berbagai informasi yang sedang dicari. 5) Shareable, artinya video yang terunggah di YouTube bisa dibagikan ke situs lainnya dengan cara mengirimkan link yang tercantum dalam aplikasi. 6) Interaktif, maksudnya adalah adanya fasilitas kolom komentar untuk melakukan tanya jawab [22] YouTube dimanfaatkan dalam media belajar sudah diriset oleh Lestari pada Ref. [23] menunjukkan bahwa video menjadi suatu media belajar yang dapat dimanfaatkan dengan mengunggahnya di Youtube. Hasil penelitian tentang pemanfaatan YouTube lain yaitu pada penelitian berjudul pemanfaatan media YouTube untuk meningkatkan hasil belajar pada peserta didik kelas VB SD Negeri Mentasan 02 Tahun Pelajaran 2020/2021 menemukan bahwa penggunaan media YouTube mampu mengalami peningkatan terhadap hasil belajar siswa.

Aplikasi yang keempat yang dimanfaatkan dalam pembelajaran di masa pandemi ini yaitu aplikasi Google Classroom memiliki fitur berbagai forum pembelajaran untuk pendidikan yang membuat guru efisien, berbagi, serta mengkategorikan tiap tugas hanya melalui aplikasi [13]. Google Classroom adalah aplikasi berfitur ruang kelas dalam media online. Fitur berupa metode pemberian tugas rumah, pengajuan pekerjaan rumah bahkan evaluasi pekerjaan rumah yang diserahkan [24]. Google Classroom dapat memberikan informasi online kepada siswa sejauh mungkin untuk menyampaikan informasi secara keseluruhan, yang juga dapat membantu guru memberikan pekerjaan rumah [25]. Aplikasi Google Classroom dapat didownload melalui playstore untuk android dan bisa juga diakses melalui web pada PC. Melalui hasil wawancara yang telah dilaksanakan bersama guru serta peserta didik pada pembelajaran daring kelas $\mathrm{V}$ Google Classroom dimanfaatkan sebagai media dalam mengumpulkan tugas-tugas peserta didik. Classroom mempunya kelebihan aplikasi dibandingkan antara aplikasi lainnya serta dapat pula digunakan dalam pengelolaan kelas, pekerjaan rumah, penilaian, dan guru dapat memberi bimbingan secara langsung. Siswa bisa meninjau materi maupun tugas yang diberikan, bisa juga saling berbagi materi bahkan melakukan interaksi melalui email, mengirimkan tugas dan memperoleh input nilai secara langsung [25]. Aimiuwu dalam Ref. [26] menemukan di tahun 2019 judulnya Google Classroom: What Works dan Bagaimana Cara Kerjanya? Ini menunjukkan bahwa Google Kelas memiliki kelebihan karena praktis digunakan, hemat ruang, berbasis cloud, terarah, serta gratis. Mengingat Google Classroom cocok digunakan di sekolah dasar. Selain itu, Google Classroom dapat membantu memantau pembelajaran siswa. Jadi Google Classroom disebut sebagai layanan dari Google melalui internet serta menerapkan metode kelas online atau E-learning yang mampu merancang media efisien, interaktif dan juga efektif terhadap pembelajaran sebagai penunjang pembelajaran berbasis pada teknologi.

Selain Google Classroom, guru juga memanfaatkan Google Form yang merupakan sebuah layanan dari Google Docs. Google Form dapat dimanfaatkan guru memberikan soal evaluasi baik evaluasi pembelajaran maupun evaluasi semester. Fauzi dalam Ref. [27] menyatakan penggunaan Google Form sebagai alat dalam melakukan evaluasi pembelajaran yang diawali dengan melakukan perencanaan, tersedianya sarana dan prasarana, mengembangkan Google Form hingga menuju tahap penerapan akses Google Form terhadap kegiatan evaluasi proses belajar yang mampu memberi dampak dan juga manfaat dalam aspek desain tampilan form, ampuh, efisien, keunikan tersendiri. Berdasarkan hasil wawancara, Guru dan peserta didik kelas $\mathrm{V}$ memanfaatkan 
aplikasi Google Form di saat Penilaian Tengah Semester (PTS) dan Penilaian Akhir Semester (PAS). Berdasarkan penelitian Susilo dalam Ref. [28] penggunaan aplikasi Google Form dalam rangka mengevaluasi pembelajaran dinilai lebih efektif daripada menggunakan media penilaian konvensional.

Pada hasil wawancara serta observasi pada tanggal 9 November, 2020 di SDN 1 Kembangbilo, Tuban didapatkan bahwa fungsi aplikasi pembelajaran terhadap guru maupun peserta didik, tidak optimal karena faktor jaringan ketika lingkungan peserta didik dan guru sedang terganggu. Sehingga berdampak pada materi pembelajaran dari guru bisa terlambat dikumpul dan terhambat untuk dikerjakan. Guru lebih menyukai mengirim teks singkat melalui WhatsApp dibanding mengirim video ataupun gambar karena, terhambatnya jaringan yang menjadi kendala. Guna menyiasati hal demikian guru bisa merancang kegiatan belajar yang disediakan KEMENDIKBUD via saluran TV di rumah atau bisa memanfaatkan koran untuk mencari sumber informasi untuk proses belajar.

Selain itu kendala yang dihadapi dalam pembelajaran jarak jauh yakni beberapa peserta didik tidak memiliki smartphone guna sebagai sarana untuk melakukan proses pembelajaran, akibatnya peserta didik yang tidak memiliki smartphone secara pribadi kesulitan untuk mengumpulkan tugas serta mengetahui informasi yang akan di disampaikan guru. Solusinya adalah sekolah atau stakeholder ikut membantu dalam menyiapkan guna untuk dipinjamkan kepada peserta didik agar pembelajaran daring yang diikuti siswa berhasil dengan baik.

\section{KESIMPULAN}

Pemanfaatan teknologi dalam pembelajaran pada kelas V di SDN 1 Kembangbilo Tuban pada masa pandemi COVID-19 yaitu berupa beberapa aplikasi yang dapat didownload melalui smartphone dan dapat difungsikan sebagai media belajar online di era COVID-19. Berdasarkan hasil penelitian menemukan adanya beragam penggunaan aplikasi yaitu aplikasi WhatsApp Massenger, Zoom Cloud Meeting, Google Classroom, dan Google Form. Beberapa aplikasi tersebut dinilai menjadi alternatif terhadap pelaksanaan proses belajar daring di era COVID-19. Namun terdapat beberapa kendala yaitu ada beberapa peserta didik yang tidak memiliki smartphone sendiri sehingga seringkali terlambat dalam mengumpulkan dan mengerjakan tugas.

\section{DAFTAR PUSTAKA}

[1] A. Yurianto, "Pedoman Pencegahan dan Pengendalian Coronavirus Disease (COVID19)," Germas, 2020.

[2] A. Hardiyana, K. Kunci, T. Informasi dan Komunikasi, and A. Usia Dini, "Optimalisasi Pemanfaatan Teknologi Informasi Dan Komunikasi Dalam Pembelajaran Paud," pp. $1-12$.

[3] J. D. Foster, W. R., \& Rosenberg, "Systemand Method For Optimizing Communications Between Session Border Controllers And Endpoints Inanetworkenvironment," Pat. Trademark Off., vol. 2, no. 12, 2013.

[4] A. Sadikin and A. Hamidah, "Pembelajaran Daring di Tengah Wabah Covid-19," BIODIK, 2020, doi: 10.22437/bio.v6i2.9759.

[5] E. Kuntarto, "Keefektifan Model Pembelajaran Daring Dalam Perkuliahan Bahasa Indonesia di Perguruan tinggi," $J$. Indones. Lang. Educ. Lit., vol. 3, no. 1, pp. 5365, 2017.

[6] Y. Bilfaqih and M. N. Qomarudin, "Esensi Pengembangan Pembelajaran Daring," Deepublish, 2015.

[7] N. S. Hanum, "Keefetifan e-learning sebagai media pembelajaran (studi evaluasi model pembelajaran e-learning SMK Telkom Sandhy Putra Purwokerto)," J. Pendidik. Vokasi, vol. 3, no. 1, pp. 90-102, 2013, doi: 10.21831/jpv.v3i1.1584.

[8] M. Nakayama, H. Yamamoto, R. Santiago, and S. Bernardino, "The Impact of Learner Characteristics on Learning Performance in Hybrid Courses among Japanese Students," Learning, 2006.

[9] K. Parker, A. Lenhart, and K. Moore, "The digital revolution and higher education: College presidents, public differ on value of online learning.," Pew Internet Am. Life Proj., 2011.

[10] K. M. Parker Kim, Lenhart Amanda, "The Digital Revolution and Higher Education College Presidents, Public Differ on Value of Online Learning The Digital Revolution and Higher Education College Presidents, Public Differ on Value of Online Learning," no. 202, 
2011.

[11] S. Unger and W. Meiran, "Student Attitudes Towards Online Education during the COVID19 Viral Outbreak of 2020: Distance Learning in a Time of Social Distance," Int. J. Technol. Educ. Sci., vol. 4, no. 4, pp. 256-266, 2020, doi: 10.46328/ijtes.v4i4.107.

[12] B. McKenna, D. Finamore, E. Valerie Hewitt, L. Watson, L. A. Millam, and M. Reinhardt, "The effect of a multifactor orientation on student performance: organizational skills, goal setting, orientation to classroom, and academic support," Online Learn. J., vol. 22, no. 4, pp. 265-276, 2018, doi: 10.24059/olj.v22i4.1207.

[13] N. K. S. Astini, "Pemanfaatan teknologi informasi dalam pembelajaran tingkat sekolah dasar pada masa pandemi covid-19," J. Lemb. Penjaminan Mutu STKIP Agama Hindu Amlapura, 2020.

[14] K. Wilson and A. Narayan, "Relationships among individual task self-efficacy, selfregulated learning strategy use and academic performance in a computer-supported collaborative learning environment," Educ. Psychol., vol. 36, no. 2, pp. 236-253, 2016, doi: 10.1080/01443410.2014.926312.

[15] Sahyar and R. Y. Fitri, "The Effect of Problem-Based Learning Model (PBL) and Adversity Quotient (AQ) on Problem-Solving Ability," Am. J. Educ. Res. Vol. 5, 2017, Pages 179-183, 2017.

[16] N. W. Abdulmajid, A. Pramuntadi, A. B. Riyanto, and E. Rochmah, "Penerapan ELearning Sebagai Pendukung Adaptive Learning Dan Peningkatan Kompetensi Siswa Smk Di Kabupaten Bantul," Taman Vokasi, 2017, doi: 10.30738/jtvok.v5i2.2475.

[17] Nurmalina, "Hubungan Penerapan Bahasa Indonesia dengan Pengembangan Kepribadian Peserta Didik PAUD Kualu Ceria," J. Paud Tambusai, vol. 2, no. 1, pp. 73-78, 2016.

[18] M. Nazir, "Metode Penelitian," in Metode penelitian, Jakarta: Ghalia Indonesia, 1999, p. 63.

[19] S. Narti, "Pemanfaatan 'Whatsapp' Sebagai Media Komunikasi Dosen Dengan Mahasiswa Bimbingan Skripsi (Studi Analisis Deskriptif
Pada Mahasiswa Ilmu Komunikasi Bimbingan Skripsi Universitas Dehasen Bengkulu Tahun 2016 )," Prof. J. Komun. dan Adm. Publik, vol. 4, no. 1, 2018, doi: 10.37676/professional.v4i1.448.

[20] D. Haqien and A. A. Rahman, "Pemanfaatan Zoom Meeting Untuk Proses Pembelajaran Pada Masa Pandemi Covid-19," SAP (Susunan Artik. Pendidikan), vol. 5, no. 1, pp. 51-56, 2020.

[21] D. Ismawati and I. Prasetyo, "Efektivitas Pembelajaran Menggunakan Video Zoom Cloud Meeting pada Anak Usia Dini Era Pandemi Covid-19," J. Obs. J. Pendidik. Anak Usia Dini, 2020, doi: 10.31004/obsesi.v5i1.671.

[22] C. Snelson, K. Rice, and C. Wyzard, "Research priorities for YouTube and videosharing technologies: A Delphi study," Br. J. Educ. Technol., 2012, doi: 10.1111/j.14678535.2010.01168.x.

[23] R. Lestari, "Penggunaan Youtube sebagai Media Pembelajaran Bahasa Inggris," Semin. Nas. Kedua Pendidik. Berkemajuan dan Menggembirakan (The Second Progress. Fun Educ. Semin., 2013.

[24] Z. Hammi, “"Implementasi Google Classroom Pada Kelas Xi Ipa Man 2 Kudus,'” 2017.

[25] A. B. Hakim, "Efektifitas Penggunaan ELearning Moodle, Google Classroom Dan Edmodo," i-statement, p. 2(1), 2016.

[26] E. E. Aimiuwu et al., "Google classroom: What works and how?," J. Educ. Soc. Sci., 2019.

[27] M. R. Fauzi, "Penggunaan Google Form Sebagai Alat Evaluasi Pembelajaran Pada Mata Pelajaran Bahasa Indonesia: Studi Deskriptif Analitis pada Kelas VIII di Sekolah Menengah Pertama Negeri 1 Lembang," Dr. Diss. Univ. Pendidik. Indones., 2014.

[28] A. Susilo et al., "Coronavirus Disease 2019 : Tinjauan Literatur Terkini Coronavirus Disease 2019 : Review of Current Literatures," J. Penyakit Dalam Indones., 2020. 